\title{
Formulation Factors of Fenvalerate Microcapsules Influencing Insecticidal Efficacy and Fish Toxicity
}

\author{
Toshiro Ohtsubo, Hisami Takeda, Shigenori Tsuda, \\ Michio Kagoshima and Kozo Tsuji \\ Pesticides Research Laboratory, Takarazuka Research Center, Sumitomo Chemical Co., Ltd. \\ Takatsukasa, Takarazuka 665, Japan
}

(Received November 12, 1988)

\begin{abstract}
The influence of formulation factors of fenvalerate microcapsules, particle size and wall thickness on insecticidal efficacy against Plutella xylostella and Spodoptera litura and fish toxicity to Olyzias latipes was studied. The insecticidal efficacy of the microcapsules was affected by parameter $D / T$, the ratio of mass median diameter $(D)$ to wall thickness $(T)$, which was considered to be related to the strength of microcapsules. The fish toxicity of the microcapsules was affected by parameter $D \cdot T$, the multiplication of $D$ and $T$, which was considered to be related to the release rate of fenvalerate encapsulated in microcapsules. These results suggest that a very important factor to prepare excellent microcapsules for agricultural use with high insecticidal efficacy and low fish toxicity is to control parameters $D / T$ and $D \cdot T$.
\end{abstract}

\section{INTRODUCTION}

New types of insecticidal formulations with newer and more useful characteristics have been developed for agricultural use. ${ }^{1)}$ Especially much work has been done on microencapsulated insecticides, because microencapsulation is favorable for the improvement of residual efficacy, the stabilization of insecticides against environmental degradation and the reduction of mammalian toxicity, fish toxicity, phytotoxicity, irritation, etc..$^{2-5}$ Such characteristics have been said to be affected by microcapsule-formulation factors, such as kinds of wall materials, particle size and wall thickness, which regulate the physicochemical properties of microcapsules. ${ }^{6}$

We studied the relationship between such factors and the residual efficacy of fenitrothion microcapsules against German cockroaches previously and reported that the residual efficacy was controlled by parameter $D / T$, the ratio of mass median diameter to wall thick- ness of microcapsules. ${ }^{7)}$

In the present study, we prepared fenvalerate microcapsules and examined formulation factors that affect the efficacy to agricultural pests and the toxicity to fish.

\section{MATERIALS AND METHODS}

\section{Microencapsulation Procedure}

Microcapsules were prepared by interfacial polymerization. The wall material was polyurea $^{8)}$ and the core material fenvalerate (Sumicidin ${ }^{\circledR}$, Sumitomo Chemical Co., Ltd., 10 percent in the final microcapsule slurry). The mass median diameter of microcapsules was controlled by changing mixing conditions when the mixture of fenvalerate and polyisocyanate as a reactant to make the wall of microcapsules was dispersed in water. Wall thickness was controlled by changing the feeding amount of polyisocyanate. The actual mass median diameter of a microcapsule was measured with a Coulter Counter Model TA-II (Coulter Electronics Inc.) and the wall thick- 
ness $(T)$ was calculated by using the following equation $^{9)}$ :

$$
T=\left(W_{\mathrm{w}} / W_{\mathrm{c}}\right)\left(\rho_{\mathrm{c}} / \rho_{\mathrm{w}}\right)(D / 6)
$$

where $W_{\mathrm{w}}=$ weight of the wall material, $W_{\mathrm{c}}=$ weight of the core material, $\rho_{\mathrm{w}}=$ density of the wall material, $\rho_{\mathrm{c}}=$ density of the core material and $D=$ mass median diameter.

\section{Contact Toxicity Test against Plutella xylostella}

The microcapsules were diluted with water containing $200 \mathrm{ppm}$ Tokusei Rino as a sticker to prescribed concentrations. Cabbage leaves at a nursery stage were dipped into the diluted microcapsules for $1 \mathrm{~min}$ and dried. Ten larvae (3rd instar) of Plutella xylostella were confined to contact with the treated leaves in a plastic cup. The $\mathrm{LC}_{50}$ was determined after $48 \mathrm{hr}$.

\section{Contact Toxicity Test against Spodoptera litura}

The microcapsules were diluted with water containing $200 \mathrm{ppm}$ Tokusei Rino as a sticker to prescribed concentrations. Potato leaves at a nursery stage were dipped into the diluted microcapsules for $1 \mathrm{~min}$ and dried. Ten larvae (3rd instar) of Spodoptera litura were confined to contact with the treated leaves in a plastic cup. The $\mathrm{LC}_{50}$ was determined after $48 \mathrm{hr}$.

\section{Residual Efficacy Test against Plutella xylostella}

The microcapsules were diluted with water containing $200 \mathrm{ppm}$ Tokusei Rino as a sticker to prescribed concentrations. The diluted microcapsules were thoroughly sprayed to potted cabbage. The cabbage was kept for a predetermined period in a greenhouse. Then, the leaves were cut and ten larvae (3rd instar) of Plutella xylostella were confined to contact with the treated leaves in a plastic cup. The mortality was determined after $48 \mathrm{hr}$.

\section{Fish Toxicity Test to Olyzias latipes}

The microcapsules were diluted with water to prescribed concentrations and ten individuals of Olyzias latipes were released in the diluted microcapsules. The $\mathrm{LC}_{50}$ was determined after $48 \mathrm{hr}$ and compared with that of fenvalerate.

\section{RESULTS AND DISCUSSION}

\section{Insecticidal Activity of Fenvalerate Micro- capsules}

As shown in Table 1, the contact toxicity of fenvalerate microcapsules against Plutella xylostella was affected by wall thickness and mass median diameter. When the wall thickness was kept almost the same, the bigger the mass median diameter, the lower the $\mathrm{LC}_{50}$. When the mass median diameter was kept almost the same, the thinner the wall, the lower the $\mathrm{LC}_{50}$.

When the $\mathrm{LC}_{50}$ values of the microcapsules were plotted vs. $D / T$, the ratio of mass median diameter $(D)$ to wall thickness $(T)$, there was

Table 1 Toxicity of fenvalerate microcapsules against Plutella xylostella.

\begin{tabular}{ccc}
\hline \multicolumn{2}{c}{ Samples } & $\begin{array}{c}\text { LC }_{50} \text { as active } \\
\text { ingredient after } \\
\text { 48 hr }(\mathrm{ppm})\end{array}$ \\
\hline$D(\mu \mathrm{m})^{\mathrm{a})}$ & $\left.T(\mu \mathrm{m})^{\mathrm{b}}\right)$ & 12.2 \\
52.0 & 0.011 & 14.9 \\
30.0 & 0.113 & 4.0 \\
22.5 & 0.002 & 14.2 \\
4.8 & 0.051 & 34.9 \\
4.8 & 0.011 & 18.2 \\
4.3 & 0.002 & $>100$ \\
2.0 & 0.038 & 21.0 \\
\hline
\end{tabular}

a) Mass median diameter.

b) Wall thickness.

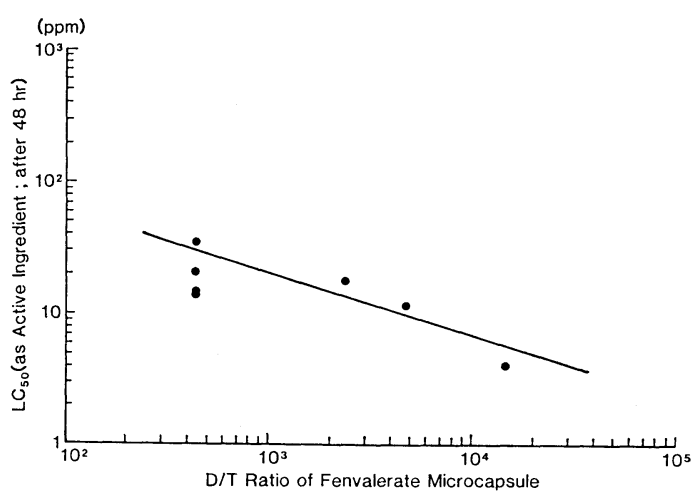

Fig. 1 Relationship between the toxicity of fenvalerate microcapsules against Plutella $x y$ lostella and $D / T$.

$D / T$ : (mass median diameter)/(wall thickness). 


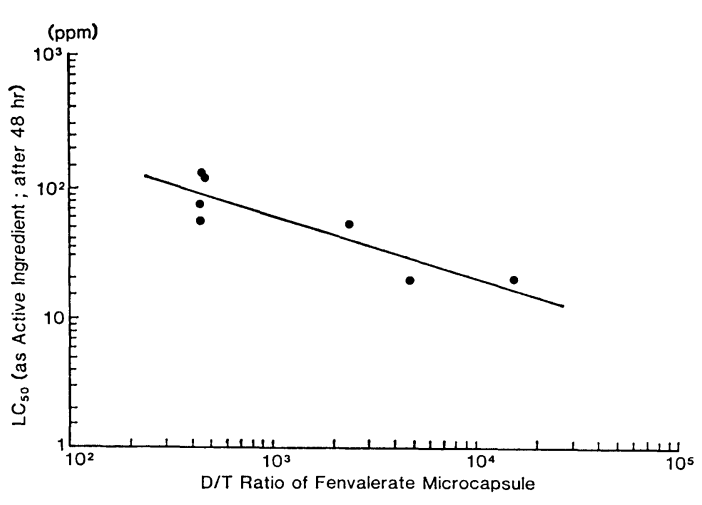

Fig. 2 Relationship between the toxicity of fenvalerate microcapsules against Spodoptera litura and $D / T$.

$D / T$ : (mass median diameter)/(wall thickness).

a linear relationship between the two values (Fig. 1). That is to say, the $\mathrm{LC}_{50}$ decreased as the $D / T$ ratio increased. The result was similar when Plutella xylostella was replaced by Spodoptera litura (Fig. 2).

\section{Residual Efficacy of Fenvalerate Micro- capsules}

Table 2 shows the residual efficacy of fenvalerate microcapsules against Plutella xylostella. When the $D / T$ ratio was higher than 400 , the residual efficacy of the microcapsules

Table 2 Residual efficacy of fenvalerate microcapsules against Pleutella xylostella.

\begin{tabular}{rrrrrrr}
\hline & Samples $^{\mathrm{a})}$ & \multicolumn{4}{c}{ Mortality (\%) } \\
\hline & & & \multicolumn{3}{c}{ Days after treatment } \\
\cline { 5 - 8 }$\left.D(\mu \mathrm{m})^{\mathrm{b}}\right)$ & $T(\mu \mathrm{m})^{\mathrm{c})}$ & $D / T$ & 0 & 14 & 21 & 28 \\
\hline 4.3 & 0.038 & 113 & 87 & 63 & 90 & 7 \\
2.0 & 0.005 & 400 & 100 & 97 & 93 & 100 \\
50.0 & 0.113 & 442 & 100 & 100 & 97 & 90 \\
4.8 & 0.002 & 2400 & 100 & 97 & 97 & 93 \\
52.0 & 0.011 & 4727 & 100 & 100 & 97 & 90 \\
31.0 & 0.002 & 15,500 & 100 & 100 & 93 & 100 \\
\hline Fenvalerate & $\mathrm{EC}^{\mathrm{d})}$ & 100 & 97 & 83 & 80 \\
\hline
\end{tabular}

a) Treated concentration: $100 \mathrm{ppm}$ as active ingredient.

b) Mass median diameter.

c) Wall thickness.

d) Emulsifiable concentrate. was higher than that of fenvalerate emulsifiable concentrate.

Our previous paper reported that the main action of fenitrothion microcapsules against German cockroaches was "trampling effect" (cockroaches trample microcapsules while crawling and contact to fenitrothion) and that the residual efficacy was controlled by the $D / T$ ratio which was considered to be related to the strength of microcapsules. ${ }^{7)}$ The same parameter $D / T$ could be introduced to control the insecticidal efficacy of fenvalerate microcapsules against caterpillar insects such as Plutella xylostella and Spodoptera litura, because that caterpillar insects would also break microcapsules when they crawl on them on a plant. The strength of microcapsules is considered to be a major factor that affects the efficacy of microcapsules against general crawling insect pests, and it is controlled by parameter $D / T$.

\section{Fish Toxicity of Fenvalerate Microcapsules}

The ratios between the $\mathrm{LC}_{50}$ of microcapsules to Oryzias latipes and that of fenvalerate were calculated as "fish toxicity-reduction ratio" and were plotted vs. $D \cdot T$, the multiplication of mass median diameter $(D)$ and wall thickness $(T)$ (Fig. 3). There was a linear relationship: the fish toxicity decreased as the mass median diameter and/or the wall thickness of microcapsules increased.

The fish toxicity of fenvalerate micro-

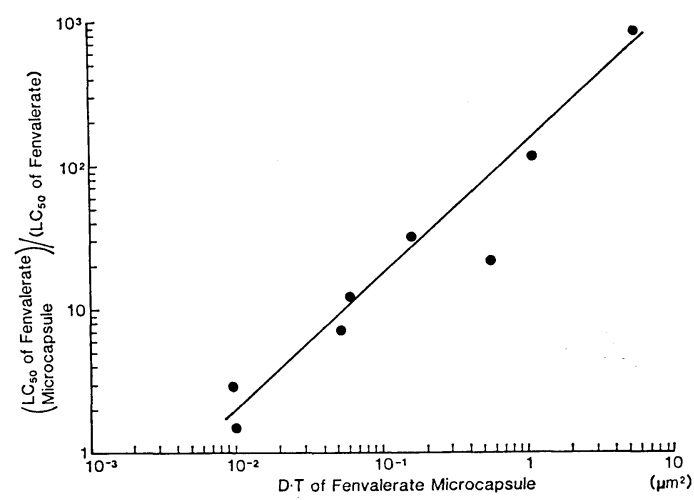

Fig. 3 Relationship between the fish toxicity of fenvalerate microcapsules to Oryzias latipes and $D \cdot T$.

$D \cdot T$ : (mass median diameter) $\times$ (wall thickness). 
capsules is thought to be caused by the active ingredient released through the wall into water by diffusion. Consequently, the fish toxicity is supposed to be affected by the release rate of fenvalerate through the wall. The release rate from a microcapsule was therefore analyzed theoretically.

As a rule, the release rate of a chemical through a membrane is controlled by diffusion. ${ }^{10,11)}$ For a slab or sandwich geometry, Fick's law can be restated;12)

$$
R=k \Delta C d_{\mathrm{r}} A_{\mathrm{s}} / l
$$

where $R=$ release rate through the membrane, $k=$ rate constant, $\Delta C=$ difference in concentration between the inside and the outside of the wall, $d_{\mathrm{f}}=$ diffusion coefficient, $A_{\mathrm{s}}=$ surface area of the device and $l=$ thickness of the membrane.

Considering the release of a chemical from a single microcapsule, Eq. (2) is modified;

$$
R_{\mathrm{s}}=k \Delta C d_{\mathrm{f}}\left(4 \pi D^{2}\right) / T
$$

where $R_{\mathrm{s}}=$ release rate of a chemical from a single microcapsule, $D=$ diameter of a microcapsule and $T=$ wall thickness of a microcapsule. When a dosage of microcapsules is $W$, the number of microcapsules used $\left(N_{\mathrm{T}}\right)$ is as follows;

$$
N_{\mathrm{T}}=(W / \rho) /\left((4 / 3) \pi D^{3}\right)
$$

where $\rho=$ density of microcapsules.

Then, the total release rate of a chemical from the microcapsules $\left(R_{\mathrm{T}}\right)$ is given by the following equation;

$$
R_{\mathrm{T}}=R_{\mathrm{S}} N_{\mathrm{T}}
$$

Substitution of Eqs. (3) and (4) into Eq. (5) and rearrangement give

$$
R_{\mathrm{T}}=3 k \Delta C d_{\mathrm{f}} W / \rho D T
$$

Equation (6) shows that $D \cdot T$ is inversely proportional to the release rate of a chemical from microcapsules.

Now, it is ascertained that the parameter $D \cdot T$ influences the release rate of fenvalerate to water, and that $D \cdot T$ is therefore the factor that affects the fish toxicity of microcapsules.

On the other hand, the insecticidal efficacy of fenvalerate microcapsules against caterpillar insects such as Plutella xylostella and Spodoptera litura was not influenced by $D \cdot T$, the parameter of release rate, but influenced by $D / T$, the parameter of strength.
When microcapsules are sprayed on plants, there are two factors to be taken into account for the release of fenvalerate, since microcapsules are in contact with air, not with water. One is the release of fenvalerate through the wall onto the microcapsule surface, and the other the evaporation of fenvalerate from the microcapsule surface into the air. The evaporation rate of fenvalerate is supposed to be remarkably slow because its vapor pressure is low $\left(1.1 \times 10^{-8} \mathrm{mmHg}\right.$ at $\left.25^{\circ} \mathrm{C}\right) .^{13)}$ Therefore, fenvalerate released outside the microcapsules through the wall may remain on the microcapsule surface. Under such a condition, $\Delta C$ of Eq. (6), which is the difference in the concentration of fenvalerate between the inside and the outside of the wall, remains almost zero. Since $\Delta C$ is the driving force of release through the wall, the release rate of fenvalerate through the microcapsule wall may be negligible at the end.

The above findings suggest that fenvalerate released outside the microcapsules by diffusion is not sufficient, if any, to kill insects when the microcapsules are sprayed and dried on plants. The microcapsules is efficacious when trampled and this efficacy is affected by $D / T$.

Our conclusion: the insecticidal efficacy is controlled by $D / T$ and the fish toxicity is controlled by $D \cdot T$ when insecticides are microencapsulated.

\section{ACKNOWLEDGMENTS}

The authors express their thanks to Mr. Y. Manabe for his skillful technical assistance in preparing microcapsules. The authors are also indebted to Sumitomo Chemical Co., Ltd. for the permission to publish this work.

\section{REFERENCES}

1) F. Horide, H. Fuyama, R. Yoshida \& K. Tsuji: J. Pesticide Sci. 10, 211 (1985)

2) G. W. Bennet \& R. D. Lund: Pest Control 45 , 44 (1977)

3) M. Sakurai, M. Kurosaki, S. Asaka, T. Umino \& T. Ikeshoji: Jpn. Sanit. Zool. 33, 301 (1982)

4) D. Dragan \& A. Carpov: J. Microencapsulation 4, 97 (1987)

5) H. B. Schar: "Pesticide Chemistry: Human Welfare and the Environment," ed. by J. Miyamoto and P. C. Kearney, Vol. 4, Pergamon Press, Oxford, pp. 295-300, 1983 
6) S. Tsuda, T. Ohtsubo, H. Kawada, Y. Manabe, N. Kishibuchi, G. Shinjo \& K. Tsuji: $J$. Pesticide Sci. 12, 23 (1987)

7) T. Ohtsubo, S. Tsuda, H. Kawada, Y. Manabe, N. Kishibuchi, G. Shinjo \& K. Tsuji: J. Pesticide Sci. 12, 43 (1987)

8) Sumitomo Chemical Co., Ltd.: Jpn Pat., Publication (laid open) No. 62-215504

9) P. L. Madan, L. A. Luzzi \& J. C. Price: J. Pharm. Sci. 63, 280 (1974)

10) W. I. Higuchi: J. Pharm. Sci. 56, 315 (1967)

11) J. G. Wanger: J. Pharm. Sci. 58, 1253 (1969)

12) R. W. Baker: "Controlled Release of Biologically Active Agents," ed. by A. C. Tanquary and R. E. Lacy, Plenum Press, New York, pp. 15-71, 1974

13) "Farm Chemical Handbook '85," ed. by R. T. Meister, G. L. Berg, C. Sine, J. Poplyk \& G. Schilling, Meister Publishing Co., Ohio, pp. C105, 1985

\section{要約 \\ 殺虫効力と魚毒性に及ぼすフェンバレレートマ イクロカプセルの製剤要因}

大坪敏朗，竹田久己，津田重典 籠島通夫，辻 孝三

ポリウレアを膜物質に用いたフェンバレレートマイク ロカプセルを調製し，その製剤要因（粒径，膜厚）とコ ナガ，八スモンヨトウに対する殺虫効力およびヒメダカ に対する魚毒性について検討した，ハスモンヨトウおよ びコナガに対する殺虫効力はカプセル強度を表わすパラ メーターである体積平均径 $(D)$ と膜厚 $(T)$ の比，すな わち $D / T$ 比と関連し，この值が大きいほど向上した. 一方, ヒメダカに対する魚毒性は $D$ と $T$ の積, すなわ ち $D \cdot T$ 值が大きくなるほど軽減された. この值はマイ クロカプセルからの有効成分の溶出に関連するパラメー ターであり，值が大きいほど溶出が抑制され，その結果 魚毒性を軽減できたものと考えられた．優れた効力を有 し，しかも魚毒性の軽減されたマイクロカプセルを調製 するためには，この二つのパラメーターに注目し，粒 径, 膜厚を最適化することが必要であると結論づけられ た。 